\title{
Analysis of the Influence of Asset Structure and Sales Growth on Capital Structure and its Impact on Corporate Profitability
}

\author{
Slamet Mudjijah ${ }^{1}$ \\ \{slamet.mudjijah@budiluhur.ac.id ${ }^{1}$ \} \\ Faculty of Economy, Universitas Budi Luhur, Jl. Ciledug Raya, Jakarta, Indonesia
}

\begin{abstract}
This study aimed to determine the effect of asset structure and sales growth on capital structure and its impact on corporate profitability. The population in this study was food and beverage companies listed on the Indonesia Stock Exchange. Sampling technique used purposive sampling technique, and the number of samples used as many as 9 companies. The method used was multiple linear regression analysis. The results showed that the assets structure affect the capital structure. While sales growth did not affect the capital structure. The asset structure and sales growth had no effect on profitability.
\end{abstract}

Keywords: Asset Structure, Sales Growth, Capital Structure, Profitability.

\section{Introduction}

The competition of building construction companies must be supported by appropriate funding decisions through the design of appropriate capital structures. In addition to anticipate the development of free market in the construction industry, the construction services industry in Indonesia needs to improve the quality of its products as a business strategy to remain exist and competitive.

Things that must be considered by the company to face the phenomenon is, one of them, the funding factor. Funding is required by the company to finance its operations and expansion. Funds can come from internal and external sources. Internal sources are funds generated by the company itself in the form of holding profit and accumulated depreciation, while external sources of funds is generated from outside the company such as funds from creditors and owners. Companies must be able to raise funds both from within and outside the company efficiently, therefore it needs an optimal balance between the two sources of funds.

One of the most important decisions facing by the company in relation to the company's operations is the decision on the capital structure, which is the description of the company's financial proportion between its own capital derived from long-term liabilities and shareholder equity, which is the source of a company's financing [1].

Capital structure is an important thing to be noted and analysed because the capital structure can describe the long-term risk borne by the company as long as the company is operating. The right funding decisions can be one of the company's efficiency factors that can impact the increase in corporate profits. The asset structure in this study is measured by 
comparing fixed assets with total assets [2], companies that have large fixed assets can use large amounts of debt this is because the large scale companies will be easier to get access to resources compared to small companies. Then the amount of fixed assets can be used as collateral or collateral debt company. In a study conducted by Tangiduk et al. (2017) show that result of the research indicates that asset structures have significant effect to capital structure. While in research conducted by Solikhadi (2016) shows that the structure of the asset has no significant effect on capital structure [3],[4].

Sales growth shows changes in sales volume in the coming years based on historical sales volume growth data [5]. In the construction company, the advance paid by the consumer is the attachment of the sales transaction, so the change in sales will cause the company's debt to be higher. The research conducted by Novione et al. (2016) showed that sales growth has an effect on capital structure, however, unlike the research by Maryanti (2016)that sales growth has no effect on capital structure [6],[7].

The research of Chisti et al.(2013) reveal that capital structure (DER) has a negative effect on profitability [8]. The study of Qiliao et al. (2015)present that capital structure has a positive effect on profitability [9].

This study aims to examine the factors that can affect the capital structure, including the assets structure and sales growth and its impact on corporate profitability.

The need for funds to strengthen the capital structure of an enterprise can be sourced internally and externally, in condition that the required funding source is from places that are considered safe (safety position), and if it used, it will have a thrust value in strengthening the financial capital structure of the company. In other words, when the funds are used to strengthen the capital structure of the company, the company is able to control the capital effectively and efficiently and on target. In addition, the company should consider whether the funding decision will either use its own capital or foreign capital, both of which have each advantages and risks.

\subsection{Profitability}

Profitability is the net result of a series of policies and decisions. Profitability describes the level of profit earned by the company within a certain period. Profitability can be assessed in various ways, one of which is using ratio [10], profitability is the relationship between income and costs generated by using company assets, both current and fixed, in production activities. Profitability can be assessed in various ways, one of which is using ratio. Profitability ratio according to Gitman (2012) is the ratio used to measure management effectiveness based on the return of the investment sale as well as the company's ability to generate profits that will be the basis of company dividend distribution [10]. The usual ratios used to measure profitability include Return on Assets.

According to Brigham (2011), return on assets can measure the profitability of the company [11]. Weygandt et al. (2012) states that "an overall measure of profitability is return on assets [12]. We compute this ratio by dividing net income by average assets". According to Stice (2004) return on asset is the financial ratios used to assess the overall profitability of a company from the point of return on assets [13]. The lower the return on asset ratio, the less good, and vice versa, the higher the return on asset ratio, the better. The calculation of return on asset formula is as follows:

Net Profit

Return on Asset $=$ 


\subsection{Capital Structure}

Total Asset

According to Fahmi (2016), the need for funds to strengthen the capital structure of a company can be sourced from internal and external, external sources can be used with the provision that is considered safe (safety position) and if used, it has a value thrust in strengthening the company's financial capital structure. In other words, when the funds are used to strengthen the capital structure of the company, the company is able to control the capital effectively and efficiently and on target [1].

Determination of capital structure will involve the exchange between risk and return. The higher risks associated with larger debt are likely to lower share prices, but a higher rate of return forecasts caused by larger debt will raise the stock's price. The company will seek to find a capital structure that produces a balance between risks and return that will maximize share prices [11].

According to Sartono (2015), Capital Structure is a balance of the amount of short-term debt of a permanent nature, long-term debt, preferred stock, and common stock [2]. The capital structure can be measured using the following formula:

$$
\text { Capital Structure }=\frac{\text { Total Debt }}{\text { Total Equity }}
$$

\subsection{Sales Growth}

Van Horne (2005) state that the key to most cash budgets is sales forecasts with an internal sales forecast approach done by projecting sales in the next period [14]. According to Rudianto (2012), Sales Growth is the volume of sales in the coming year based on historical sales volume growth data [5]. A good company can be identified from its sales from year to year that continues to increase, these rights impact on increasing corporate profits so that internal funding will also increase.

According to Fabozzi (2001), Sales Growth represents a change in sales on annual financial statements. The above average Sales Growth of a company is generally based on the expected rapid growth of the industry in which it operates [15].

Companies can achieve above average growth rates by increasing market share of overall industry demand. Furthermore, Maryanne (2008) state that "Several possible objectives are associated with revenue growth [16]. New products and services are developing new customers and markets, and adopting a new pricing strategy". Thus, sales growth is an indicator of demand and companies competitiveness in an industry. The growth rate of an enterprise will affect the strategy of retaining profits in funding future opportunities.

Sales growth can be measured by the following formula:

$$
\text { Sales Growth }=\frac{\text { Sales }_{\mathrm{t}}-\text { Sales }_{\mathrm{t}-1}}{\text { Sales }_{\mathrm{t}-1}}
$$

Note:

Sales t: Sales of a particular year

Sales t-1: Sales of the previous year 


\subsection{Asset Structure}

Assets are resources controlled by a company for the purpose of generating profits, consisting of current assets and non-current assets (fixed assets). Current assets are resources or claims on resources that can be directly converted into cash throughout the company's operating cycle. Fixed assets are resources or claims to resources that are expected to benefit companies for several periods [17].

The asset structure represents the proportion of fixed assets of total assets owned by a company, most companies that are mostly invested in fixed assets will prioritize the capital fulfilment of the permanent capital which is its own capital, while its debt is complementary. However, the asset structure can describe part of the amount of collateral value of assets. Companies that have debt guarantees will find it easier to get debt than companies that have no collateral. Companies that have assets that can be used as debt collateral tend to use relatively large debt [18]. The calculation of asset structure formula as follows:

$$
\text { Asset Structure }=\frac{\text { Fixed Assets }}{\text { Total Assets }}
$$

\subsection{Influence of Asset Structure to Capital Structure}

As stated earlier that the asset structure is one of the important variables in determining funding decisions, because the fixed assets owned by a company can be collateral for the creditor in doing loan. Asset Structure which is the ratio between fixed assets to total assets will greatly affect the company's capital structure. The capital structure is the ratio between the long-term debt and the capital itself used by the company. While the capital itself can be regarded as a company asset. The greater the assets structure owned by the company, the greater the loan that can be obtained by the company on the guarantee given to the creditor. So it will affect the value of the capital structure as well. Previous research conducted [19], Tangiduk et al. (2017) revealed the result that the assets structure significantly influence the capital structure [3].

H1: The structure of assets has a positive effect on capital structure

\subsection{Influence of Sales Growth on Capital Structure}

According to Van Horne (2005), the key to most cash budgets is sales forecasts with an internal sales forecast approach done by projecting sales in the next period [14]. According to Rudianto (2012), sales growth is the volume of sales in the coming year based on historical sales volume growth data [5]. A good company can be identified from its sales from year to year that continues to increase, it will impact on the increasing need for funds to finance operational activities. In accordance with balancing theories, the company will seek additional funds with loans either to banks, leasing or also by issuing bonds to finance the increase in operational activities. This is supported by Mahnaz mahdavi et al. (2013) and Alnajjar (2015) studies which show significant sales growth in capital structure [20],[21]. Based on the description, the hypothesis proposed as follows:

$\mathrm{H} 2$ : Sales growth positively affects the capital structure. 


\subsection{Effect of Asset Structure on Profitability}

Profitability ratio is a ratio that measures the company's ability to generate profit (profitability) at the level of sales, assets, and capital. ROA shows how much a company's ability to generate profits by utilizing its assets. The asset structure shows that tangible assets are more easily monitored and can provide guarantees between shareholders and creditors.

H3: The asset structure has a positive effect on profitability.

\subsection{The Influence of Sales Frowth on Profitability}

A good company can be identified from its sales from year to year which continues to increase. Sales growth shows the company's ability to survive in competitive conditions. The higher sales growth compared to the increase in cost will lead to increase the corporate profits. The amount of profit earned on a regular basis and an increasing trend or profit trend are the factor that determines the company to survive. While companies with negative sales growth ratios have great potential to decrease in profits so that if management does not take immediate corrective action, the company may not be able to maintain its survival. Subowo (2015) in his research states that sales growth has a positive direction on operating income [22]. Based on the description above, the hypothesis proposed is as follows:

H4: Sales growth has a positive effect on profitability.

\subsection{The Influence of Capital Structure on Profitability and the Role of Capital Structure in Mediating the Influence of Asset Structure and Growth on Profitability}

Capital structure and profitability have a relationship that cannot be ignored, in which both have relationships that affect each other. That is because companies need increased profitability in order to survive in a long term and will affect the value of the company. Among those are the size of the value of the company to the social and environment needs of the company, the interest payment of tax deductible debt, and the addition of debt in the capital structure will increase the profitability of the company. Previous research conducted by Gill et al. (2011) note that the relationship of capital structure has a positive effect on profitability [23].

H5: Capital structure has a positive effect on profitability.

H6: Capital structure can increase the influence of assets structure on profitability.

H7: Capital structure can increase the effect of sales growth on profitability.

\section{Research Methods}

The population in this study is food and beverage companies listed on the Indonesia Stock Exchange. Sampling technique used is purposive sampling which is the selection of samples with consideration or certain criteria.

The criteria is which the company published the financial statements in 2012 until 2016. Companies that meet the criteria are 9 (nine) companies. 
The analysis in this research used linear regression method by using SPSS 22 program. This research examines the effect of asset structure variable and sales growth on capital structure and its impact on profitability. To test the data before being processed, classical assumption test is done with the aim that the data to be processed meets the basic criteria of data processing. The data testing step is done by step: normality test, multi collinearity test, heteroscedasticity test, and autocorrelation test. After the basic criteria test, it can be concluded that the data used is feasible to be used or researched. Next, test the hypothesis and Sobel test (Test Mediator). Sobel test is a test to determine whether the relationship through a mediation variable is significantly capable as a mediator in the relationship [24]. The test formula is as follows:

$$
Z=\frac{a b}{\sqrt{\left(b^{2} S E a^{2}\right)+\left(a^{2} S E b^{2}\right)}}
$$

Where:

a $=$ Regression coefficient of independent variable to mediation variable.

$\mathrm{b} \quad=$ regression coefficient of mediation variable to dependent variable.

$\mathrm{SEa}=$ standard error of estimation of the influence of independent variables on mediation variables.

$\mathrm{SEb}=$ standard error of estimation in from the influence of the mediation variable to the dependent variable.

Regression step is done 3 times, the first regression is done between asset structure variable and sales growth to capital structure; second, asset structure and sales growth on profitability; and last, capital structures to profitability.

\section{Result And Discussion}

Based on the classical assumption test, the research data has met the criteria for further processing. The pattern of distribution curves in the histogram charts tend to have a balanced slope between the left and right sides, then the residual data can be declared as in normal distribution. All variables have tolerance values $>0.1$ and Variance Inflation Factor (VIF) $<10$. Thus it can be concluded that there is no multi col linearity. Durbin-Watson values are between -2 and +2 , so it can be concluded there is no autocorrelation problem in the regression model.

The Scatterplot image shows the spots did not spread randomly and not scattered above and below the number 0 on the $\mathrm{Y}$ axis. This indicates that there is a problem of heteroscedasticity in the regression model. One way to overcome the heteroscedasticity gel is to transform the data into the form of natural logarithm (ln). The result of heteroscedasticity test after data transformation showed that the scatterplot pattern image was not detected heteroscedasticity symptoms.

Hypothesis testing conducted in this study used multiple linear regression analysis by using SPSS version 20.0, which is presented in three stages. The first stage is to test the hypothesis that there is influence of asset structure and sales growth on capital structure. 
Table 1. Analysis results on multiple regression I.

\begin{tabular}{llrrr}
\hline & & \multicolumn{2}{c}{ Unstandardized } & \\
\cline { 3 - 4 } & & \multicolumn{1}{c}{ Coefficients } & \multirow{2}{*}{ Sig. } \\
\cline { 3 - 4 } 1 & (Constant) & -1.832 & .866 & .040 \\
& LN-asset structure & 1.313 & .228 & .000 \\
& LN-sales growth & .078 & .072 & .282 \\
\hline
\end{tabular}

From these results, it can be concluded that the asset structure variable has a positive effect on capital structure. The significance used is $5 \%$ or 0.05 . The significance value of the asset structure is $0.00<0.05$, thus $\mathrm{H} 1$ is accepted. This means that the asset structure has a positive and significant effect on the capital structure.

Variable of sales growth have positive effect to capital structure. Value significance of $0.282>0.05$, thus $\mathrm{H} 2$ is rejected. This means that sales growth has a positive and insignificant effect on capital structure.

The second stage is to test the hypothesis that there is influence of asset structure and sales growth on profitability.

Table 2. Analysis results of multiple regression II.

\begin{tabular}{llrrr}
\hline & & \multicolumn{2}{c}{$\begin{array}{c}\text { Unstandardized } \\
\text { Coefficients }\end{array}$} & \multirow{2}{*}{ Sig. } \\
\cline { 2 - 4 } & & \multicolumn{1}{c}{ B } & \multicolumn{1}{c}{ Std. Error } & \\
\hline \multirow{2}{*}{1} & (Constant) & 2.982 & 1.059 & .007 \\
\cline { 2 - 4 } & LN-asset structure & -.274 & .279 & .332 \\
\cline { 2 - 4 } & LN-sales growth & .110 & .088 & .214 \\
\hline
\end{tabular}

From these results, it can be concluded that the variable asset structure negatively affect profitability. The significance used is $5 \%$ or 0.05 . The significance value of the asset structure is $0.332<0.05$, thus $\mathrm{H} 3$ is rejected. This means the asset structure has a negative and insignificant effect on profitability.

Variable of sales growth have positive effect to capital structure. Value significance of $0.214>0.05$, thus $\mathrm{H} 4$ is rejected. This means that sales growth has a positive and insignificant effect on profitability.

The third stage is to test the hypothesis that there is influence of capital structure to profitability. 
Table 3. Analysis results of multiple regression III.

\begin{tabular}{llrrr}
\hline & & \multicolumn{2}{c}{ Unstandardized } & \\
\cline { 3 - 4 } & & \multicolumn{1}{c}{ B } & Std. Error & \\
\hline 1 & (Constant) & -1.832 & .866 & .040 \\
& LN-capital structure & -.441 & .125 & .001
\end{tabular}

From these results, it can be concluded that the variable of capital structure has a negative effect on profitability. The significance used is $5 \%$ or 0.05 . The significance value of the asset structure is $0.001<0.05$, thus $\mathrm{H} 5$ is accepted. This means that the capital structure has a negative and significant effect on profitability.

Sobel test in this research is used to test the hypothesis that capital structure is able to mediate the influence of asset structure and sales growth on profitability.

Based on the value of the asset structure coefficient, $\mathrm{z}$ value is obtained from the test sobelat 15.638. Because the $\mathrm{z}$ value obtained is greater than 1.98 with a significance level of $5 \%$, thus H6 is accepted. This proves that the capital structure is able to mediate the influence of assets structure on profitability. Based on the value of sales growth coefficientz value is obtained from the test sobelat 31.178.Becausethe value of $\mathrm{z}$ obtained is greater than 1.98 with a significance level of 5\%,thus $\mathrm{H} 7$ is accepted. This proves that the capital structure is able to mediate the effect of sales growth on profitability.

\section{Conclusion}

Based on the results of the analysis, it can be concluded:

1. Structure of assets have a positive effect on capital structure.

2. Sales growth has no effect on capital structure.

3. The asset structure has no effect on profitability.

4. Sales growth has no effect on profitability.

5. Capital structure negatively affect profitability.

6. Capital structure able to increase the influence of asset structure to profitability.

7. Capital structure can increase the effect of sales growth on profitability.

Based on the conclusions obtained in this study, it is recommended to:

1. Company managers must be able to consider the funding decisions that will be taken, either using own capital or debt. Funding is expected to increase corporate profits.

2. Investors. This research is expected to be a consideration for investors in deciding the investment to be made, so as to get the optimum return possible.

In this research, there are some limitations of research sample which only in sub-sector of food and beverage company. Profitability as a dependent variable is proxied only with return on asset so it does not reflect overall profitability. It is advisable for further researchers who interested in similar topics to expand sub-sectors that not just food and beverage companies. 
Profitability variables should be proxied with different angles such as net profit margin, return on equity and so forth.

\section{References}

[1]I. Fahmi, Pengantar Manajemen Keuangan Teori dan Soal Jawab. Bandung: Alfabeta., 2016.

[2]A. Sartono, Manajemen Keuangan Teori dan Aplikasi, 4th ed. Yogyakarta: Media Komputindo, 2015.

[3]P. V. R. dan J. T. Tangiduk, Desmianti, Rate, “Analisis Pengaruh Ukuran Perusahaan, Struktur Aktiva, dan Provatibilitas terhadap Struktur Modal pada Perusahaan Manufaktur Sektor Industri Dasar dan Kimia yang terdaftar di Bursa Efek Indonesia Periode 2011-2015.,” J. EMBA, vol. 5, no. 2, 2017.

[4]L. M. Solikhadi, "Faktor-Faktor Yang Mempengaruhi Struktur Modal”, vol. 5, 2016.

[5]Rudianto, Pengantar Akuntansi: Konsep dan Teknik Penyusunan Laporan Keuangan Adaptasi IFRS. Jakarta: Erlangga, 2012.

[6]N. M. Novione Purnama Dewi Suweta and M. Rusmala Dewi, "Pengaruh Pertumbuhan Perjualan, Struktur Aktiva, dan Pertumbuhan Aktiva Terhadap Struktur Modal,” E-Jurnal Manaj. Unud, vol. 5, no. 8, pp. 5172-5199, 2016.

[7]E. Maryanti, “Analisis Profitabilitas, Pertumbuhan Perusahaan, Pertumbuhan Penjualan Dan Struktur Aktiva Terhadap Struktur Modal Pada Perusahaan Sektor Industri Barang Konsumsi Yang Terdaftar Di Bursa Efek Indonesia," Ris. Akunt. dan Keuang., vol. 1, no. 2, pp. 143-151, 2016.

[8]K. A. Chisti, K. Ali, and M. Sangmi, "Impact of Capital Structure on Profitability of Listed Companies ( Evidence From India ),” USV Ann. Econ. Public Adm., vol. 13, no. 1, pp. 183-191, 2013.

[9]A. S. S. Qiliao, E. Chongqing, L. Ze-, L. I. U. Hu, C. Bin, and X. Jian-, "The Effect Of Capital Structure On Profitability: An Empirical Analysis Of Listed Firms In Iraq,” vol. 34, no. 6, pp. 61-78, 2015.

[10]L. J. Gitman, Principles of Manajerial Finance. United States: Pearson Addison Wesley, 2012.

[11]E. F. and J. F. H. Brigham, Essentials of Financial Management: Dasar-Dasar Manajemen Keuangan, Kesebelas. Jakarta: Salemba Empat, 2011.

[12]D. E. K. Weygandt, Jerry J., Paul D. Kimmel, Financial Accounting IFRS Edition. United States of America: John Wiley \& Sons, 2012.

[13]S. J. D. dan S. K. F. Stice, Akuntansi Intermediate. Jakarta: Salemba Empat, 2004.

[14]J. C. dan W. J. M. J. Van Horne, Fundamental of Financial Management: Prinsip-prinsip Manajemen Keuangan. Jakarta: Salemba Empat, 2005.

[15]F. Fabozzi., J, Manajemen Investasi, Satu. Jakarta: Salemba Empat, 2001.

[16]H. dan M. Maryanne, Managerial Accounting, Eighth. United States of America: Thomson Higher Education, 2008.

[17]S. J. J. Wild, Analisis Laporan Keuangan. Jakarta: Salemba Empat, 2010.

[18]B. Riyanto, Dasar-Dasar Pembelanjaan Perusahaan, 4th ed. Jakarta: Fakultas Ekonomi dan Bisnis UGM, 2011.

[19]D. W. Fith Yuniar Ichwan, "Pengaruh Ukuran Perusahaan, Struktur Aktiva dan Profitabilitas terhadap Struktur Modal,” J. Ilmu Ris. Akunt., vol. 4, no. 6, pp. 1-19, 2015.

[20]Mahnazmahdavi, Mokhtarbaseri, A. Zare, and H. Zare, "The effect of sales growth on the determinants of capital structure of listed companies in Tehran Stock Exchange Department of Accounting, Science and Research Branch, Islamic Azad University, Khouzestan, Iran,” vol. 7, no. 2, pp. 306-311, 2013.

[21]M. I. M. Alnajjar, "Business Risk Impact on Capital Structure: A Case of Jordan Industrial Sector,” Glob. J. Manag. Bus. Res. C Financ., vol. 15, no. 1, 2015.

[22]Subowo, "Pengaruh Pertumbuhan Penjualan, Perputaran kas, Perputaran Piutang, Perputaran Persediaan dan Perputaran Modal Kerja terhadap Laba Usaha," Ekonomi, vol. 1, no. 1, 2015.

[23]A. Gill, N. Biger, and N. Mathur, "The Effect of Capital Structure on Profitability: Evidence from 
the United States.,” Int. J. Manag., vol. 28, no. 4, pp. 3-15, 2011

[24]I. Ghozali, Aplikasi Analisis Multivariate dengan Program IBM SPSS 23, 8th ed. Semarang:

Badan Penerbit Universitas Diponegoro, 2016 